\section{PERCENT TIME-SPENT-FOLLOWING MODEL FOR SINGLE CARRIAGEWAY ROAD}

\author{
Lee Vien Leonga*, Shafida Azyanti Mohd Shafieb, Wins Cott Gohc \\ aUniversiti Sains Malaysia, 11800 USM Penang, Malaysia \\ bMajlis Perbandaran Seberang Perai, Bandar Perda, 14000 Bukit \\ Mertajam, Pulai Pinang, Malaysia \\ Intelliroad Services, 25-2, Menara Promenade, 189 Jalan Tun \\ Razak, 50400 Kuala Lumpur, Wilayah Persekutuan
}

Article history

Received

30 January 2019

Received in revised form

26 August 2019

Accepted

5 September 2019

Published online

24 October 2019

*Corresponding author

\section{Graphical abstract}

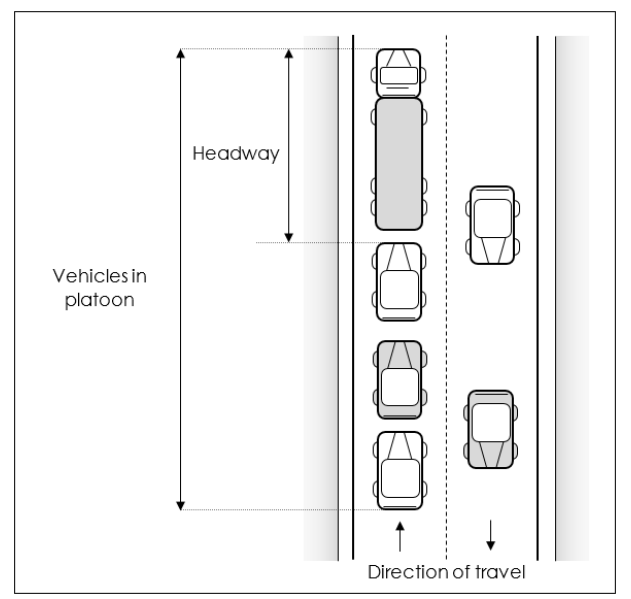

\begin{abstract}
Percent time-spent following (PTSF) is an important parameter in determining level-of-service of a single carriageway road but the current performance measure adopted in Malaysia is based on volume over capacity ( $\mathrm{v} / \mathrm{c}$ ) ratio. Therefore, this study aims to develop a new PTSF model that is suitable for single carriageway roads in Malaysia. Traffic flow at 32 sites in various states in Malaysia were recorded using CCTV and video camera. Image processing software was used to extract volume, speed and headway data. Surrogate measure which is the percentage of vehicles travelling with headway threshold values of 3.0 and 5.0 seconds were used in estimating PTSF in the field. Initially, the base PTSF (BPTSF) model was developed and subsequently used to develop six different PTSF models using headway threshold values of 3.0 and 5.0 seconds and different variables. Analyses and performance indicators showed that the model developed based on the headway threshold value of 5.0 seconds with the inclusion of percentage of no-passing zone, opposing flow rate and percentage of heavy vehicles is the best model. This model was determined as the best fit as it has the highest score of 15 , which is the maximum score based on performance indicator analysis.
\end{abstract}

Keywords: Single carriageway road, percent time-spent-following, headway, vehicle platoon, opposing flow rate

\begin{abstract}
Abstrak
Peratus masa mengekori (PTSF) adalah parameter penting dalam menentukan tahap perkhidmatan jalan raya tunggal tetapi ukuran prestasi semasa yang diterima pakai di Malaysia hanya berasaskan nisbah keupayaan berbanding kapasiti ( $\mathrm{v} / \mathrm{c}$ ). Oleh itu, kajian ini bertujuan untuk membangunkan model PTSF baru yang sesuai untuk jalan raya tunggal di Malaysia. Aliran trafik di 32 lokasi di seluruh Malaysia telah dirakam menggunakan CCTV dan kamera video. Perisian pemprosesan imej digunakan untuk mengekstrak data aliran, kelajuan dan jarak kepala. Kaedah gantian iaitu peratusan kenderaan yang bergerak dengan nilai jarak kepala ambang 3.0 saat dan 5.0 saat digunakan untuk menganggar PTSF di lapangan. Pada mulanya, model asas PTSF (BPTSF) dibangunkan dan kemudiannya digunakan untuk membangunkan enam model PTSF yang berbeza menggunakan nilai ambang jarak kepala 3.0 dan 5.0 saat dan pembolehubah yang berlainan. Analisis dan petunjuk prestasi menunjukkan bahawa model yang dibangunkan berdasarkan nilai jarak kepala ambang 5.0 saat dan mengambil kira peratusan zon tidak memotong, kadar aliran bertentangan dan peratusan kenderaan berat adalah model
\end{abstract}


terbaik. Model ini ditentukan sebagai yang paling sesuai kerana ia mempunyai skor tertinggi 15, iaitu skor maksimum berdasarkan penunjuk prestasi.

Kata kunci: Jalan dua-lorong dua-hala, peratus masa mengekori, jarak kepala, platun kenderaan, kadar aliran arah bertentangan

(C) 2019 Penerbit UTM Press. All rights reserved

\subsection{INTRODUCTION}

Maintaining the desired speed is comparatively more challenging for a two-lane, two-way or single carriageway road than multilane road since chances to overtake are less. Overtaking a slower vehicle requires the use of the opposing lane with sufficient sight distance and gaps in the traffic stream. The amount of overtaking opportunities available is dependent on headway and speed distribution of a given traffic volume [1]. On a single carriageway road with overtaking restrictions, driver frustration will be caused by the inability of the driver to drive at the preferred speed due to a slow leading vehicle. Drivers that are travelling at less than their perceived ideal speed due to lack of overtaking opportunities will cause formation of platoons. According to U.S. Highway Capacity Manual 2000 [1], a platoon is defined as a group of vehicles or pedestrians travelling together as a group, either voluntarily or involuntarily because of signal control, geometrics or other factors. In practical terms, vehicular platoons have mostly been defined in terms of time headway. Headway is the "time, in seconds, between two successive vehicles as they pass a point on the roadway, measured from the same common feature of both vehicles (for example, the front axle or the front bumper) [1]. Therefore, vehicles that travel at relatively high speeds are still part of the platoons as long as the headway of the following vehicle is considered short [2]. This situation expresses the condition where the platooning is an important phenomenon on single carriageway roads.

In the U.S. Highway Capacity Manual 1985 [3], the average speed was considered as an inadequate measurement to quantify passing demand in relation with passing supply. Therefore, in that edition of the Highway Capacity Manual, a new measure for determining level-of-service (LOS) for two-lane, twoway highways, which is the percent time delay (PTD) was introduced. The procedures involved in calculating PTD is based on the assumption that cars were travelling in platoons when they were travelling less than their desired speeds at headways less than 5 seconds. The percentage of vehicles that met these criteria was used as a surrogate measure to PTD.

Hoban [4] noted that the use of traffic platooning as the service measure for two-lane roads was a major improvement in the U.S. Highway Capacity Manual 1985 [3]. However, Hoban [4] stated that he preferred the Australian term "time spent following," rather than "percent time delay," as more clearly defining the nature of the measure. Asus such, Harwood and Hoban [5] defined percent following or spot platooning as the percentage of vehicles with headways of 5 seconds or less as they pass a given point in their study. Krumins [6] on the other hand expressed a concern based on extensive field data collected in Canada that the PTD values predicted with the U.S. Highway Capacity Manual 1985 [3] procedure was generally higher than those observed in the field. Both Guell and Virkler [7], and Johnson [8] also disagreed with the application of 5 seconds headway criterion recommended in U.S. Highway Capacity Manual 1985 [3] in the estimation of PTD from spot platooning data in the field. Guell and Virkler [7] stated that changing the definition for when a vehicle is being delayed from headway of 5 seconds, as given by the U.S. Highway Capacity Manual 1985 [3], to headway of 3.5 to 4.0 seconds would provide more useful LOS categories while Johnson [8] stated that the 5 seconds value should be replaced with headway values of between 2.5 to 3.5 seconds. Luttinen [9] however, expressed that the proportion of headways estimated on Finland rural highways for trailing vehicles was not greater than 3 seconds and he concluded that 3 seconds headway rule should be considered in the situation when the vehicle is travelling under the influence of a platoon [10]. Botma [11] studied the traffic operations on busy two-lane rural roads in the Netherlands and indicated that no preference could be deduced between headways 4, 5 , and 6 seconds, but 5 seconds was chosen as an indicator of the proportion of "hindered drivers" which is when drivers are hindered from overtaking.

However, in the fourth edition of the Highway Capacity Manual 2000 [1], the term "percent timespent-following (PTSF)" was used instead of PTD. This was done because the expression is used to determine the time spent travelling in platoons and not the delay. Also, it was concluded in the manual, that the 5 seconds headway threshold value was too high, and a lower value would provide better and more accurate results. Concerns such as this have led to the re-evaluation of the initial value of 5 seconds headway, which was then changed to the value to 3 seconds in order to quantify the platooning phenomenon on two-lane highways in a more realistic manner [12]. Therefore, the surrogate measure in estimating the PTSF in the field which is the percentage of vehicles travelling with headways of less than 3 seconds was used by many researchers in their studies 
about platooning behaviour at two-lane highways [2, 10, 13-17].

In the Malaysia context, Ibrahim et al. [18] however, have proposed to use the alternative method which is the moving car method to measure PTSF in the field, since it is a segment related measurement but details on how this method can be applied and the comparative results of using this method as opposed to the surrogate measure method were not given. Leong and Shafie [19] have conducted a comparative study to determine the effect of headway threshold values of 3.0 and 5.0 seconds on platooning behavior in Malaysia. Based on their results, the lowest and highest percentage of differences between platoon size based on 3.0 and 5.0 seconds were $0 \%$ and $18.96 \%$ respectively while the average percentage of difference was only $11.02 \%$. Hence, they concluded that the headway of 3.0 seconds and 5.0 seconds showed no substantial differences on average travel speed and platoon size. In another study conducted by Che Puan [20] on car following headway on single carriageway roads in Malaysia, headway value of $5.0 \mathrm{~s}$ was used in his study. $\mathrm{He}$ also suggested that the speed ratio of following vehicle to leading vehicle should be in the range of 0.9 to 1.02 .

Evidently, even though there are various headway threshold values used by various researchers to measure PTSF in their studies, the more common headway threshold values are 3.0 seconds $[1,2,10$, 12-15] and 5.0 seconds [3, $20-23$ ]. Therefore, the aim of this study was to analyze and compare the PTSF values measured using headway less than 3.0 seconds and 5.0 seconds. Additionally, this study also intends to determine the effects of vehicle composition on PTSF, by including the percentage of motorcycles and heavy vehicles in the development of PTSF estimation models. This is the unique and critical part of this study as most of the PTSF models were developed in other countries which were based on homogeneous traffic and the impact of traffic composition was not taken into consideration in their analyses. The findings from this study should improve the understanding of PTSF under mixed traffic conditions and improve the design and performance assessment of single carriageway roads in Malaysia.

\subsection{METHODOLOGY}

This study only focuses on single carriageway roads with level terrain located in rural and suburban areas of Peninsular Malaysia. Selected sites should have moderate traffic volume with a continuous flow of vehicles. The segment length is fixed at $3.50 \mathrm{~km}$, with minimum $1.0 \mathrm{~km}$ away from any signalized intersections, major intersections or access points which can affect driving behavior and vehicle speeds when they are congested during peak hours. Selected sites are then divided into sites that fulfill the base conditions and sites that do not. According to the geometric design or road guideline published by the Road Engineering Association of Malaysia [24], ideal or base conditions consist of the following:

- Design speed greater than or equal to $100 \mathrm{~km} / \mathrm{h}$

- Lane widths greater than or equal to $3.65 \mathrm{~m}$ (12')

- Clear shoulders wider than or equal to $1.83 \mathrm{~m}$ (6')

- No "No passing zones" on the highway

- All passenger cars in the traffic streams

- A 50/50 directional split of traffic

- No impediment to through traffic due to traffic control or turning vehicles

- Level terrain

Therefore, a total of 32 sites with 64 lanes in various states of Malaysia such as Kedah, Perak, Pahang, Terengganu, Selangor, Melaka, Negeri Sembilan and Johor were selected for data collection. However, only three sites with a total of six lanes, which were in Kedah, Pahang and Johor satisfied the base conditions of no no-passing zone or with very minimal no-passing zone.

In this study, data collections were conducted during typical working days; i.e. Tuesday, Wednesday and Thursday using video recording method. Surveys were conducted during peak and off-peak hours. For peak hours, data were recorded for two time periods which are 7.30 a.m. to 8.30 a.m. and 5.30 p.m. to 6.30 p.m. Similarly, for off-peak hours, data were also recorded for two time periods which are 10.00 a.m. to 12.00 p.m. and from 2.00 p.m. to 4.00 p.m.

At each site, one closed-circuit television (CCTV) and one video camera were set up simultaneously to record the traffic flow. The CCTV is mounted vertically on a 10-meter pole at the midpoint of the $3.5 \mathrm{~km}$ segment, as high as possible at the roadside to record traffic flows for both directions of travel. The video outputs from CCTV will then be used as input video in an image processing technique to obtain headways and speeds. As for video camera, it is mounted in an elevated position further away at the inner edge of the paved shoulder to record the platooning behavior of vehicles.

The videos recorded using a video camera and CCTV are then played back simultaneously to identify vehicles travelling in platoon. Vehicles are considered travelling in platoon when headway of the vehicle is less than $5.0 \mathrm{~s}$ and the ratio of speed of following vehicle to leading vehicle is between 0.9 to 1.02 [20]. Subsequently, corresponding headway and speed of each vehicle in platoon were determined.

Figure 1 shows the typical equipment set-up at the site while Figure 2 shows the plan view of the recording area. 


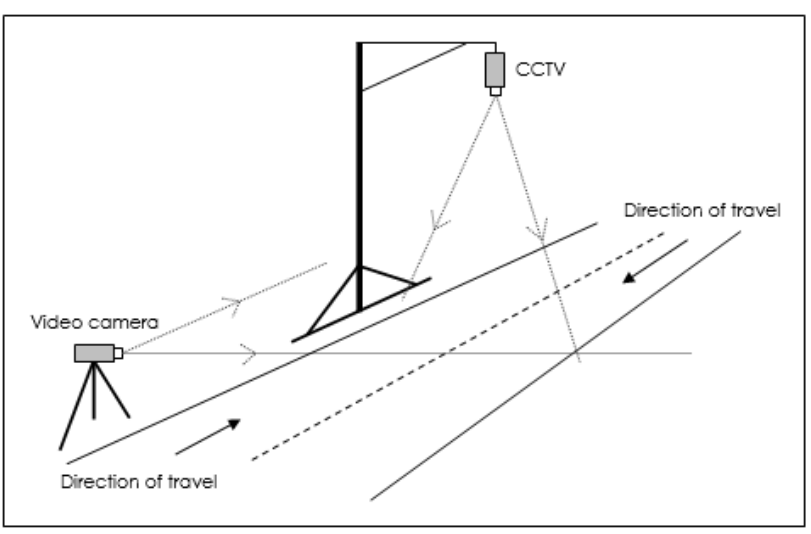

Figure 1 Equipment set-up at site with schematic diagram of the position of CCTV and video camera

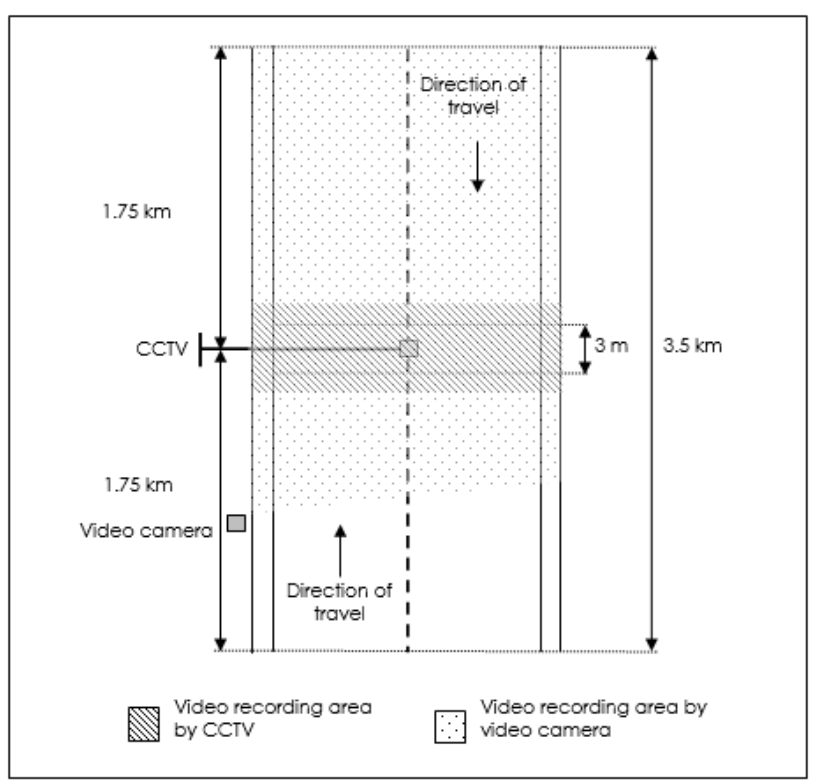

Figure 2 Plan view of the recording area

In addition, at each site, road characteristics such as lane width, paved and unpaved shoulder widths were measured at at-least three points along the segment length. The values recorded were then averaged during the analytical process. Apart from that, the length of the no-passing zone and the number of access points were also recorded. Nopassing zone is defined as the percentage of road length in which overtaking is prohibited over the 3.5 $\mathrm{km}$ road segment.

The sites were then divided into sites that fulfilled the base conditions and sites that do not fulfilled the based conditions. Data collected at sites which fulfill the base conditions which is not having any nopassing zone or with very minimal no-passing zone will be used to develop the base percent time-spentfollowing (BPTSF) model while data collected at sites with non-base conditions will be used to develop the PTSF models.

\subsection{RESULTS AND DISCUSSION}

\subsection{Average Travel Speed of Vehicles in Platoon}

As both headway and speed have a significant impact of platooning behaviour, initial analysis of the distribution of average travel speed along the 64 segments of single carriageway roads was conducted. Figure 3 shows the frequency distribution plot based on speed class of $10 \mathrm{~km} / \mathrm{h}$ for vehicles travelling in platoons which were measured from headway threshold 3.0 and 5.0 seconds. Based on the histogram plot shown in Figure 3, can be observed that for speed class than $60 \mathrm{~km} / \mathrm{h}$, higher frequencies were recorded for headway threshold of 3.0 seconds as compared to 5.0 seconds but for speed class more than $60 \mathrm{~km} / \mathrm{h}$, the opposite trend was observed. This indicates that more vehicles are travelling at higher speed for higher headway threshold value and more vehicles are travelling at lower speed for lower headway threshold value. Nevertheless, in general, most of the vehicles travelling in platoons are travelling at the speed of between $60 \mathrm{~km} / \mathrm{h}$ to $70 \mathrm{~km} / \mathrm{h}$ which are very similar with the results obtained from Che Puan [20]. This is maybe due to the reason that speed limits on the selected sites are in the range of 70 to 90 $\mathrm{km} / \mathrm{h}$.

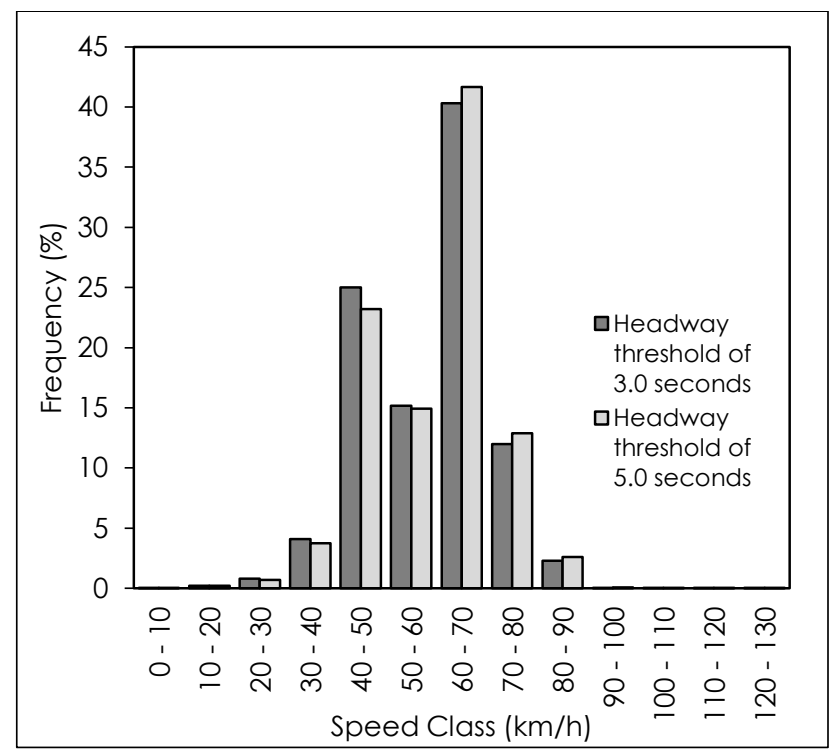

Figure 3 Frequency distribution plot based on speed class $(\mathrm{km} / \mathrm{h})$

\subsection{Base Percent Time-Spent-Following (BPTSF) Model}

The BPTSF model is essentially an exponential function that passed through the origin and asymptotically approached PTSF of $100 \%$. The model for BPTSF for twoway analysis is based on two-way demand flow rate whereas for directional analysis, the relationship between BPTSF and the directional flow rate was found to vary as a function of opposing flow rate. 
According to U.S. Highway Capacity Manual 2000 [1], opposing flow rates have an effect on BPTSF for directional analysis but not for two-way analysis. As such, for this study, both types of analysis were conducted. However, due to the limitation of data, BPTSF can only be segregated based on only four series of opposing flow rates which are between $0-$ $199 \mathrm{pc} / \mathrm{h}, 200-399 \mathrm{pc} / \mathrm{h}, 400-599 \mathrm{pc} / \mathrm{h}$ and lastly 600 - $799 \mathrm{pc} / \mathrm{h}$. Figure 4 shows the relationship between BPTSF and direction flow rate based on different series of opposing flow rates. The graph, however, shows that the BPTSF values plotted against directional flow rate are not significantly different for different series of opposing flow rates and as such, can be concluded that opposing flow rates did not have any effect on BPTSF. Therefore, only one model was developed for BPTSF, regardless whether it is for two-way analysis or directional analysis.

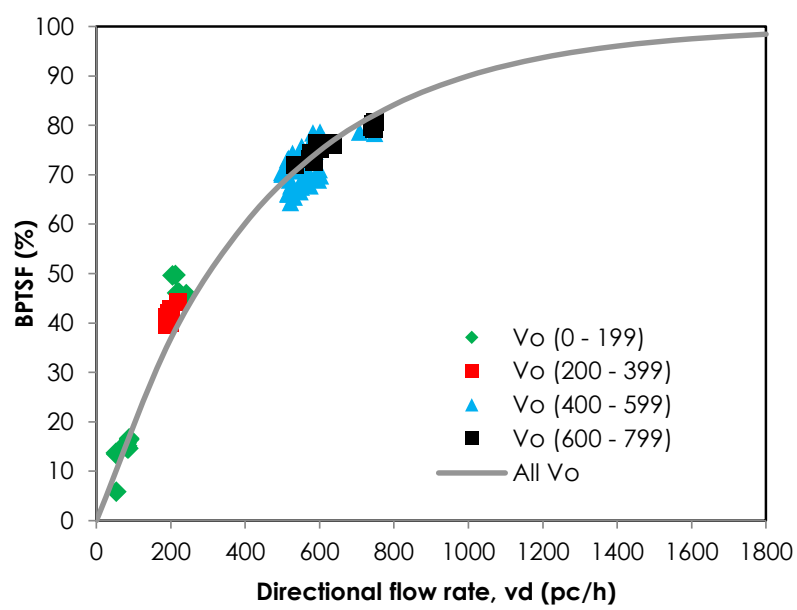

Figure 4 Relationship between BPTSF and directional flow rate for different series of opposing flow rate

Nevertheless, as two values of headway threshold values were analyzed in this study, two separate BPTSF models were developed. The regression models developed for BPTSF based on headway threshold values 3.0 with $R^{2}$ value of 0.928 and 5.0 with $R^{2}$ value of 0.928 seconds are as shown in Equations (1) and (2) respectively.

Headway threshold value 3.0 seconds

$B P T S F=100\left(1-e^{-0.002 v d}\right)$

Headway threshold value 5.0 seconds

$B P T S F=100\left(1-e^{-0.003 v d}\right)$

where $v d$ is the passenger car equivalent directional flow rate. Summary results of the regression analyses are as shown in Table 1.
Table 1 Summary of regression analysis for BPTSF model

\begin{tabular}{|c|c|c|c|c|c|}
\hline \multirow{2}{*}{$\begin{array}{l}\vec{\partial} \\
\frac{3}{0} \\
\frac{0}{1} \\
\frac{d}{x}\end{array}$} & \multirow[b]{2}{*}{ Variable } & \multicolumn{2}{|c|}{$\begin{array}{c}\text { Unstandardized } \\
\text { coefficients }\end{array}$} & \multirow[b]{2}{*}{ t-value } & \multirow[b]{2}{*}{$p$-value } \\
\hline & & B & $\begin{array}{l}\text { Standard } \\
\text { error }\end{array}$ & & \\
\hline$<3.0$ & $v d$ & -0.002 & 0.000 & -47.424 & $<0.001$ \\
\hline$<5.0$ & $v d$ & -0.003 & 0.000 & -49.994 & $<0.001$ \\
\hline
\end{tabular}

In addition, due to the reason that regression analysis requires the assumption of residual (error) to be normally distributed with zero mean and constant variances to obtain the best model, residual analyses were conducted to determine the adequacy of the regression model obtained. The normal probability plot is a graphical technique for assessing whether a data set is approximately normally distributed. To assess whether the residuals are normally distributed or otherwise, normal probability graph is plotted. The data are plotted against a theoretical normal distribution in such a way that the data points should distribute around $45^{\circ}$ straight line. Deviation from this $45^{\circ}$ straight line indicates departures from normality [25]. Based on the normal probability plot shown in Figure 5, the data points seemed to be distributed roughly around the $45^{\circ}$ straight line, indicating that the residuals are normally distributed with zero mean.

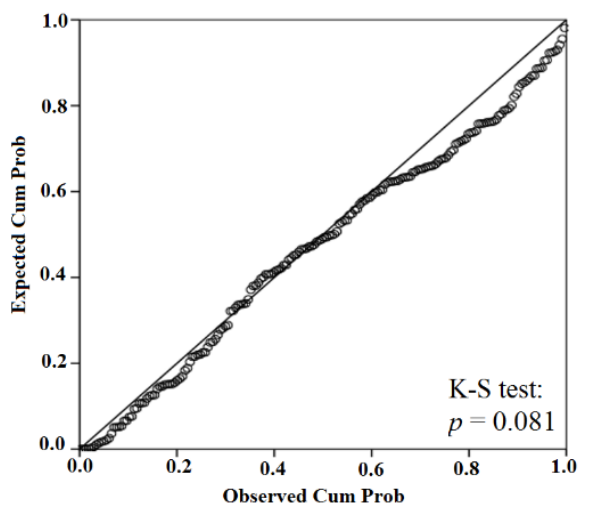

(a)

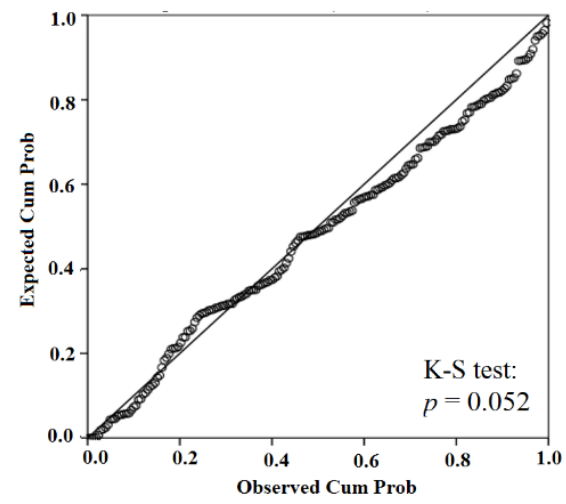

(b)

Figure $\mathbf{5}$ Normal probability plot for BPTSF model (a) headway threshold $3.0 \mathrm{~s}(\mathrm{~b})$ headway threshold $5.0 \mathrm{~s}$ 
In addition, the equal variance of errors is checked by looking at the distribution pattern of the residuals around the x-axis. Additionally, scatterplots of the residuals against the predictor variables in the model or against potential predictors that are not included in the model are the main plots used to assess the adequacy of the functional part of the model. Plots in which the residuals do not show any pattern indicate that the model fits the data well. Plots of the residuals against other predictor variables, or potential predictors that show any pattern indicate that the form of the function can be improved in some way [25]. As can be seen in Figure 6, the points plotted in the graph appear to be randomly scattered around zero, hence the assumption that the residuals have zero mean is satisfactory. Also, the vertical width of the scatter plot does not appear to increase or decrease across the fitted values, thus the variance in the residuals is constant.

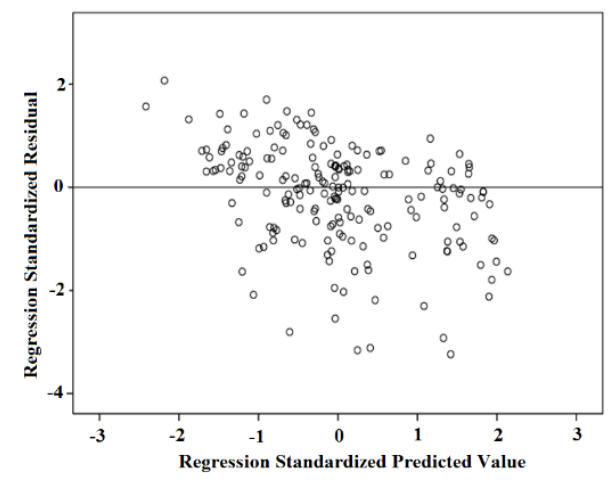

(a)

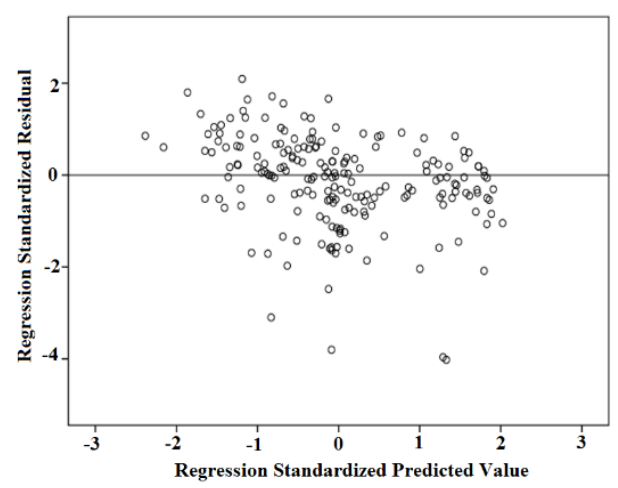

(b)

Figure 6 Residuals versus fitted values for BPTSF model (a) headway threshold $3.0 \mathrm{~s}$ (b) headway threshold $5.0 \mathrm{~s}$

\subsection{Percent Time-Spent-Following (PTSF) Models}

In the development of PTSF models, six models with three conditions were tested. Models 1, 2 and 3 were developed based on the headway threshold value of 3 seconds while Models 4, 5 and 6 were developed based on the headway threshold value of 5 seconds. Models 1 and 3 are the basic model and only takes into consideration the effect of no-passing zones (\%NPZ) on opposing flow rate while Models 2 and 5 takes into consideration the effects of \%NPZ on opposing flow rate and the effect of heavy vehicles (\%HV). Models 3 and 6 are basically the same as Models 2 and 4 but with the consideration of an additional factor which is the percentage of motorcycles (\%M). The developed models are as shown in Equations (2) to (7) for Models 1 to 6 respectively.

Headway threshold 3 seconds:

Model $1\left(R^{2}=0.465\right)$ :

$$
P T S F=B P T S F+43.604\left(\frac{\% N P Z}{v o}\right)
$$

Model $2\left(R^{2}=0.658\right)$ :

$$
P T S F=B P T S F+20.601\left(\frac{\% N P Z}{v o}\right)+0.597(\% H V)
$$

Model $3\left(R^{2}=0.678\right)$ :

$$
\begin{gathered}
P T S F=\text { BPTSF }+18.543\left(\frac{\% N P Z}{v o}\right)+0.569(\% H V)+ \\
0.037(\% M)
\end{gathered}
$$

Headway threshold 5 seconds:

Model $4\left(R^{2}=0.546\right)$ :

$$
\begin{gathered}
P T S F=B P T S F+43.281\left(\frac{\% N P Z}{v o}\right) \\
\text { Model } 5\left(\mathrm{R}^{2}=0.673\right): \\
P T S F=B P T S F+31.525\left(\frac{\% N P Z}{v o}\right)+0.394(\% H V) \\
\text { Model } 6\left(\mathrm{R}^{2}=0.678\right): \\
P T S F=\text { BPTSF }+28.708\left(\frac{\% N P Z}{v o}\right)+0.370(\% H V)+ \\
0.035(\% M)
\end{gathered}
$$

where BPTSF is the base percent-time spent following $(\%), \% N P Z$ is the percentage of no-passing zone, $v o$ is the opposing flow rate, \%HV is the percentage of heavy vehicles in the analysis direction and \%M is the percentage of motorcycles in the analysis direction. Summary of regression analysis for Models 1 to 6 are as shown in Table 2.

Based on the results shown in Table 2, can be seen that all independent variables are statistically

\begin{tabular}{|c|c|c|c|c|c|}
\hline \multirow{2}{*}{$\begin{array}{l}\bar{\Phi} \\
\text { ర0 } \\
\text { ¿ }\end{array}$} & \multirow{2}{*}{ Variable } & \multicolumn{2}{|c|}{$\begin{array}{c}\text { Unstandardized } \\
\text { coefficient }\end{array}$} & \multirow{2}{*}{ t-value } & \multirow{2}{*}{$p$-value } \\
\hline & & B & $\begin{array}{c}\text { Standard } \\
\text { error }\end{array}$ & & \\
\hline 1 & $\% N P Z / v o$ & $\begin{array}{c}43.60 \\
4\end{array}$ & 9.544 & 4.569 & $<0.001$ \\
\hline 2 & $\% N P Z / v o$ & $\begin{array}{c}20.60 \\
1\end{array}$ & 10.066 & 2.047 & 0.052 \\
\hline \multirow{4}{*}{3} & \%HV & 0.597 & 0.165 & 3.608 & 0.001 \\
\hline & $\% N P Z / v o$ & $\begin{array}{c}18.54 \\
3\end{array}$ & 11.072 & 1.675 & 0.108 \\
\hline & $\% \mathrm{HV}$ & 0.569 & 0.178 & 3.204 & 0.004 \\
\hline & $\% \mathrm{M}$ & 0.037 & 0.078 & 0.488 & 0.630 \\
\hline
\end{tabular}
significant at $95 \%$ confidence level except for the $\% N P Z / v o$ variable in Model 2 and percentage of motorcycles, \%M in Models 3 and 6 which are not statistically significant, as the $p$-value obtained is more than 0.05. Therefore, Models 2, 3 and 6 are rejected and only Models 1, 4 and 5 will be considered for further analysis to determine the best fitted PTSF model.

Table 2 Summary of regression analysis for BPTSF model 


\begin{tabular}{|c|c|c|c|c|c|}
\hline \multirow{2}{*}{$\begin{array}{l}\bar{\Phi} \\
\frac{0}{0} \\
\sum\end{array}$} & \multirow{2}{*}{ Variable } & \multicolumn{2}{|c|}{$\begin{array}{c}\text { Unstandardized } \\
\text { coefficient }\end{array}$} & \multirow{2}{*}{ t-value } & \multirow{2}{*}{$p$-value } \\
\hline & & B & $\begin{array}{l}\text { Standard } \\
\text { error }\end{array}$ & & \\
\hline 4 & $\% N P Z / v o$ & $\begin{array}{c}43.28 \\
1\end{array}$ & 9.581 & 4.517 & $<0.001$ \\
\hline 5 & $\% N P Z / v o$ & $\begin{array}{l}31.52 \\
5\end{array}$ & 9.618 & 3.278 & 0.005 \\
\hline \multirow[t]{3}{*}{6} & $\begin{array}{c}\% \mathrm{HV} \\
\% N P Z / v o\end{array}$ & $\begin{array}{c}0.394 \\
28.70 \\
8\end{array}$ & $\begin{array}{c}0.158 \\
11.373\end{array}$ & $\begin{array}{l}2.492 \\
2.524\end{array}$ & $\begin{array}{l}0.024 \\
0.023\end{array}$ \\
\hline & $\% \mathrm{HV}$ & 0.370 & 0.171 & 2.149 & 0.048 \\
\hline & $\% \mathrm{M}$ & 0.035 & 0.072 & 0.496 & 0.627 \\
\hline
\end{tabular}

Subsequently, Models 1, 4 and 5 were assessed to determine if they fulfilled the multiple linear regression assumption. Figure 6 shows the normal probability plots obtained for the PTSF models. As can be seen in Figure 7, some of the data points deviate quite far from the $45^{\circ}$ straight line which means that the normality assumption might not be satisfied with these models. Hence, another test of normality, namely Kolmogorov-Smirnov (K-S) test is conducted to check on the normality assumption. The $p$-value obtained from the K-S test for Models 1, 4 and 5 which are 0.867 , 0.847 and 0.637 respectively indicated that the null hypothesis cannot be rejected and hence the distribution for all three models can be considered as normally distributed.

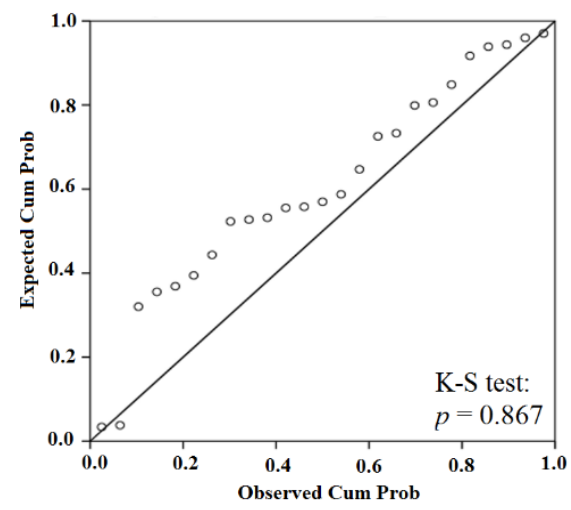

(a)

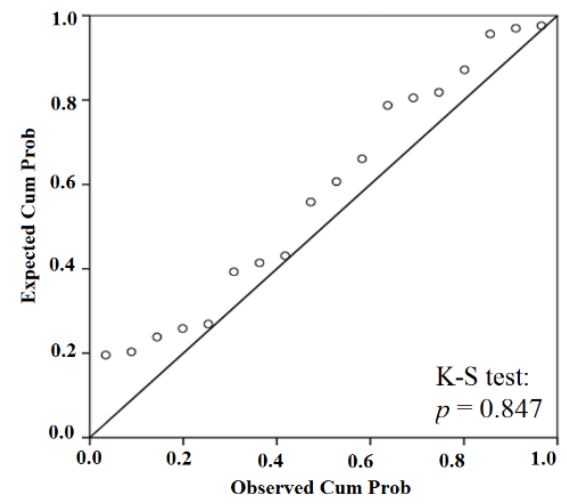

(b)

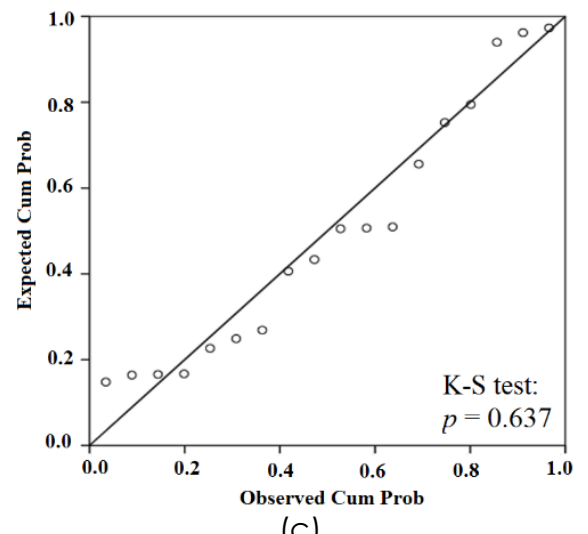

(c)

Figure 7 Normal probability plot for PTSF models (a) Model 1 (b) Model 4 and (c) Model 5

Figure 8 shows the graphs of residual versus fitted values plotted for PTSF models. The residuals plotted for Model 1 and Model 5 appear to be randomly scattered around the horizontal axis indicating that the assumption of residual which is uncorrelated with independent variables is valid. In addition, the plots also indicated that the assumption of residuals having mean zero and constant variance of the random errors are also valid. However, for Model 4, the points in the plot seem to be fluctuating randomly around zero in a pattern. Thus, the plot suggests violations of the assumptions of zero means and constant variance of the random errors.

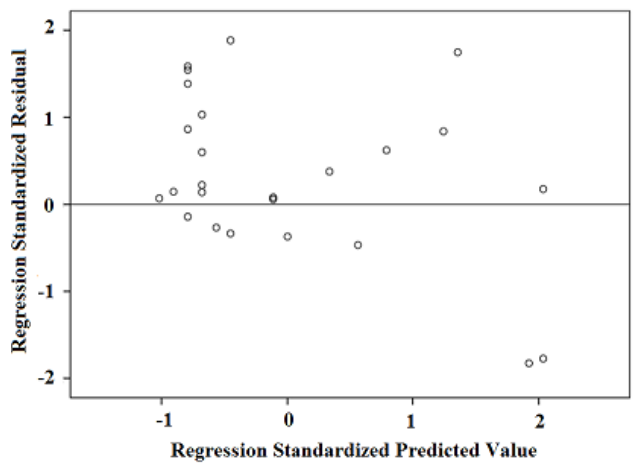

(a)

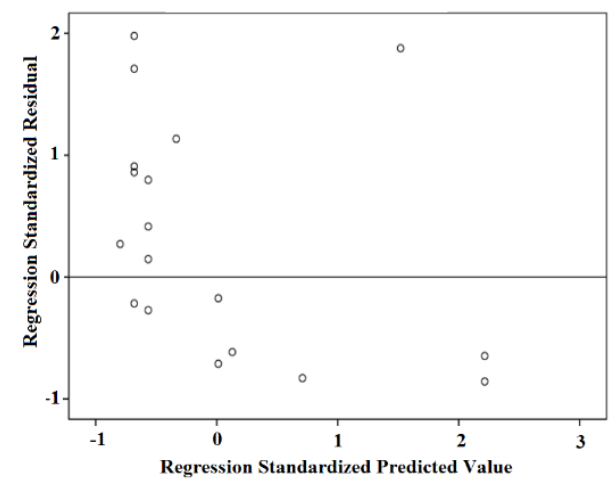

(b) 


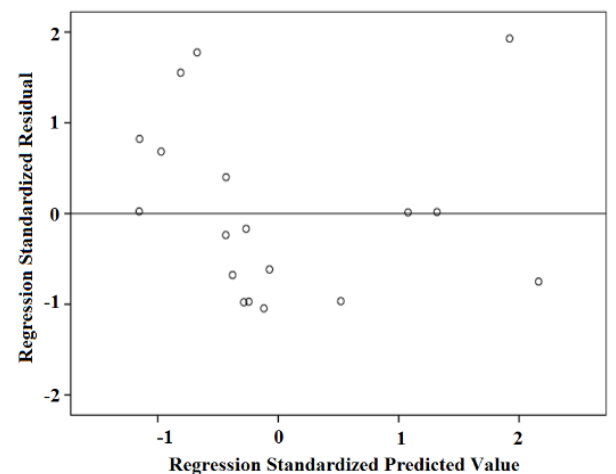

(c)

Figure 8 Residuals versus fitted values for PTSF models (a) Model 1 (b) Model 4 and (c) Model 5

\subsection{Selection of the best Percent Time-Spent-Following (PTSF) Model}

Performance indicators which consist of normalized absolute error (NAE), root mean square error (RMSE), index of agreement (IA), predictive accuracy (PA) and the coefficient of determination $\left(R^{2}\right)$ were used to determine the best PTSF model amongst the three models. For a good model, NAE and RMSE should approach zero while IA, PA and $\mathrm{R}^{2}$ should be nearer to 1. Table 3 presents the results of the performance indicator values for all PTSF models. Subsequently, for error measure, the models are ranked from highest (score $=1$ ) to smallest (score $=3$ ) while for accuracy measures, they are ranked from smallest (score $=1$ ) to highest (score $=3$ ). The total score is calculated for each PTSF model. The results obtained are shown in Table 3.

Based on the results shown in Table 3, Model 1 has the lowest score while Model 5 has the highest score. However, Model 4 is rejected because this model violated the assumptions of zero means and constant variance of random errors which are the basic requirements of multiple linear regression. Hence, the obvious choice of the best model will be Model 5. In addition, Model 5 is selected as the best model because this model has the smallest values of NAE and RMSE and the highest value of IA, PA and $R^{2}$ with a total score of 15 which is the maximum score.

Table 3 Summary of PI values for PTSF models

\begin{tabular}{|c|c|c|c|c|c|c|c|}
\hline \multicolumn{2}{|c|}{ Model } & NAE & RMSE & IA & $\boldsymbol{P A}$ & \multirow{2}{*}{$\boldsymbol{R}^{\mathbf{2}}$} & $\begin{array}{c}\text { Total } \\
\text { score }\end{array}$ \\
\hline \multirow{2}{*}{1} & Value & 0.0919 & 6.2841 & 0.9283 & 0.8829 & 0.465 & \multirow{2}{*}{5} \\
\cline { 2 - 7 } & Score & $\mathbf{1}$ & $\mathbf{1}$ & $\mathbf{1}$ & $\mathbf{1}$ & $\mathbf{1}$ & \\
\hline \multirow{2}{*}{4} & Value & 0.0630 & 4.9384 & 0.9703 & 0.9494 & 0.546 & \multirow{2}{*}{10} \\
\cline { 2 - 7 } & Score & $\mathbf{2}$ & $\mathbf{2}$ & $\mathbf{2}$ & $\mathbf{2}$ & $\mathbf{2}$ & \\
\hline \multirow{2}{*}{5} & Value & 0.0533 & 4.1535 & 0.9797 & 0.9604 & 0.678 & \multirow{2}{*}{$\mathbf{1 5}$} \\
\cline { 2 - 7 } & Score & $\mathbf{3}$ & $\mathbf{3}$ & $\mathbf{3}$ & $\mathbf{3}$ & $\mathbf{3}$ & \\
\hline
\end{tabular}

The chosen PTSF model is then compared with the model used in the U.S. Highway Capacity Manual
2000 [1] and the results obtained are as shown in Figure 9. Based on the plot in Figure 8 , can be concluded that the difference between PTSF values predicted based on the model developed in this study which is Model 5 and PTSF values estimated based on U.S. Highway Capacity Manual 2000 [1] are found to be minimal. However, can be seen from the graph that the PTSF values determined based on the PTSF model adopted in the U.S. Highway Capacity Manual 2000 [1] are slightly different than the values estimated in this study. Comparing the regression line plotted for both models, can be determined that the directional flow rates of $205.4 \mathrm{pcu} / \mathrm{h}$ is the intersection point, in which the PTSF model in the U.S. Highway Capacity Manual 2000 [1] overestimate PTSF values when directional flow rate is more than $205.4 \mathrm{pcu} / \mathrm{h}$ and underestimate PTSF values when directional flow rate is less than $205.4 \mathrm{pcu} / \mathrm{h}$. The maximum overestimation of PTSF values determined from the U.S. Highway Capacity Manual 2000 model with the values estimated from the Model 2 is $13.92 \%$ or $20.3 \%$ of difference while the maximum underestimation is $14.64 \%$ or $17.2 \%$ of difference. The overestimation occurred at a flow rate of $216 \mathrm{pcu} / \mathrm{h}$ while the underestimation occurred at flow rate of $669 \mathrm{pcu} / \mathrm{h}$. Only six sites recorded overestimation of PTSF of more than $10 \%$ while three sites recorded underestimation of PTSF of more than $10 \%$.

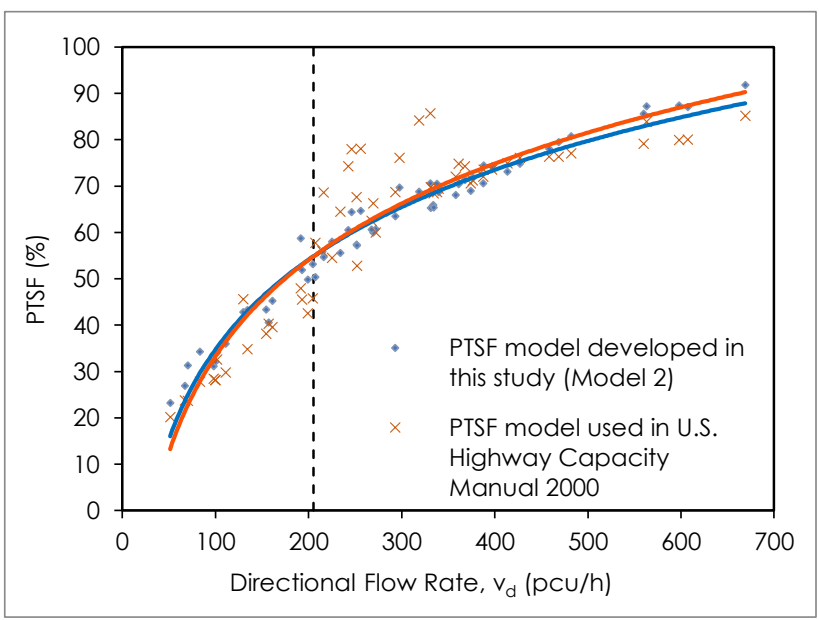

Figure 9 Comparison of PTSF model developed in this study with the PTSF model in U.S. Highway Capacity Manual 2000

\subsection{CONCLUSION}

In this study, an exponential BPTSF model which passed through the origin and asymptotically approached a value of $100 \%$ was developed and the analysis indicated that the BPTSF model was not influenced by opposing flow rate. The results obtained from statistical analysis were also satisfactory. Subsequently, the developed BPTSF model is used to develop PTSF models under three conditions in which variables such as percentages of heavy vehicles and motorcycles were included in the regression models. 
Based on the results obtained from statistical analysis, can be concluded that the PTSF model which consists of independent variables; percentage of no-passing zone, opposing flow rate and percentage of heavy vehicle is the best model. In addition, comparison between the PTSF values estimated based on this model with the PTSF values estimated using the PTSF model from US Highway Capacity Manual 2000 indicated minimal difference. The selection of Model 5 as the best model inferred that the volume of heavy vehicles has a significant impact on PTSF and should be taken into consideration in the design of single carriageway roads in Malaysia. Additionally, headway threshold value of 5.0 seconds is recommended to be used in the measurement of PTSF in Malaysia.

\section{Acknowledgement}

The authors wish to acknowledge and express their sincere gratitude to the Highway Planning Division, Ministry of Works, Malaysia for funding this research and Universiti Sains Malaysia for the support and facilities provided.

\section{References}

[1] Transportation Research Board. 2000. Highway Capacity Manual (2000). National Research Council, Washington, D.C.

[2] Al-Kaisy, A., \& Durbin, C. 2008. Evaluating New Methodologies for Estimating Performance On Two-lane Highways. Canadian Journal of Civil Engineering. 35: 777 785. DOI: 10.1139/L08-020.

[3] Transportation Research Board. 1985. Highway Capacity Manual: Special Report 209 (1985). National Research Council, Washington, D.C.

[4] Hoban, C. J. 1986. Planning and Design of Rural Roads: Observations on a Year in America. Research Report AAR No. 140, Australian Road Research Board.

[5] Harwood, D. W., \& Hoban, C. J. 1987. Low-cost Methods for Improving Traffic Operations on Two-lane Roads: Informational Guide. Report FHWA-IP-87-2, FHWA U.S. Department of Transportation.

[6] Krumins, I. 1991. Two-lane Highway Capacity and Level of Service Research Project: Phase III Final Report. Transportation Association of Canada.

[7] Guell, D. L., \& Virkler, M. R. 1988. Capacity Analysis of Twolane Highways. Transportation Research Record, 1194, TRB National Research Council, Washington, D.C. 199-205.

[8] Johnson, G. P. 1985. Highway Capacity Manual Misses Mark on Rural Highway Capacity. Proceedings of the 65th Annual Meeting, Institute of Transportation Engineers.

[9] Luttinen, R. T. 1992. Statistical Properties of Vehicle Time Headways. Transportation Research Record, 1365, TRB, National Research Council, Washington, D.C. $92-98$.
[10] Luttinen, R. T. 2001. Percent Time-spent-following as Performance Measure for Two-lane Highways. Transportation Research Record: Journal of the Transportation Research Board. 1776(1): 52-59. DOI: 10.3141/1776-07.

[11] Botma, H. 1986. Traffic Operation on Busy Two-lane Rural Roads in the Netherlands. Transportation Research Record 1091, TRB, National Research Council, Washington, D.C., 126-131.

[12] Harwood, D. W., May, A. D., Anderson, I. B., Leiman, L., \& Archilla, A. R. 1999. Capacity and Quality of Service of Twolane Highways. Kansas City, MO: Midwest Research Institute.

[13] Al-Kaisy, A., \& Freedman, Z. 2010. Estimating Performance on Two-Lane Highways. Transportation Research Record. Journal of the Transportation Research Board. 2173(1): 7279. DOI: $10.3141 / 2173-09$.

[14] Al-Kaisy, A., \& Karjala, S. 2008. Indicators of Performance on Two-Lane Rural Highways: Empirical Investigation. Transportation Research Record. Journal of the Transportation Research Board. 2071 (1): 87-97. DOI: 10.3141/2615-08.

[15] Dixon, M. P., Sarepali, S. S. K., \& Young, K. A. 2002. Field Evaluation of Highway Capacity Manual 2000 Analysis Procedures for Two-lane Highways. Transportation Research Record. Journal of the Transportation Research Board. 1802(1): 125-132. DOI: http://dx.doi.org/10.3141/1802-15.

[16] Harwood, D. W., May, A. D., Anderson, I. B., Leiman, L., \& Archilla, A. R. 1999. Capacity and Quality of Service of Twolane Highways. Kansas City, MO: Midwest Research Institute.

[17] Luttinen, R. T., Dixon, M., \& Washburn, S. 2005. Two-lane Highway Analysis in HCM 2000. Transportation Research Board. DOI: 10.13140/RG.2.1.1667.8568.

[18] Ibrahim, M. N., Che Puan, O. \& Mustaffar, M. 2013. Review of Percent Time Spent Following (PTSF) as Performance Measure for Two-lane Highways. Jurnal Teknologi. 61 (1): 918. DOI: https://doi.org/10.11113/jt.v64.1485.

[19] Leong, L. V. \& Shafie, S. A. M. 2019. Platooning Behavior at Two-Lane, Two-Way Rural Roads with Level Terrain in Malaysia. Advances in Human Aspects of Transportation. 727-738. DOI: https://doi.org/10.1007/978-3-319-93885167.

[20] Che Puan, O. 2004. Driver's Car Following Headway on Single Carriageway Roads. Jurnal Kejuruteraan Awam. 16(2): 15-27.

[21] Pursula, M., \& Enberg, A. 1991. Characteristics and Level-ofservice Estimation of Traffic Flow on Two-Lane Rural Roads in Finland. Transportation Research Record, 1320.

[22] Gattis, J. L., Alguire, M. S., Townsend, K., \& Rao, S. 1997. Rural two-lane Passing Headways and Platooning. Transportation Research Record. Journal of the Transportation Research Board. 1579(1): 27-34.

[23] Ministry of Public Works. 1995. Indonesian Highway Capacity Manual: Part II - Interurban Roads. Jakarta Indonesia.

[24] Road Engineering Association of Malaysia. 2002. REAM - GL 2/2002: A Guide on Geometric Design of Roads. Kuala Lumpur.

[25] Croarkin, C. \& Tobias, P. 2006. Nist/sematech e-handbook of Statistical Methods. NIST/SEMATECH, July [Online]. Available: http://www. itl. nist. gov/div898/handbook. [Accessed: 04-February-2014]. 